\title{
Masuknya Syarat Kerja Baru di Luar yang diperjanjikan oleh Pengusuha di PT. X Padalarang Kabupaten Bandung Barat ditinjau dari Undang- Undang No.13 Tahun 2003 tentang Ketenagakerjaan
}

\author{
Hilman Fauzan $M^{*}$, Deddy Effendy \\ Prodi Ilmu Hukum, Fakultas Hukum, Universitas Islam Bandung, Indonesia. \\ *rfauzanr@gmail.com,deddyeffendy60@gmail.com
}

\begin{abstract}
The work agreement stipulated in Article 1601 a Civil Code states the qualifications so that an agreement can be called an employment agreement. Qualifications in this case refer to the existence of work, under orders, a certain time and the existence of wages, while Article 1 number 14 of Law No. 13 of 2003, an employment agreement is an agreement between the worker or laborer with the employer or employer containing work conditions the rights and obligations of both parties. This research method uses the juridicalnormative approach, which examines secondary data by conducting a literature study. Data collection techniques used are secondary data using primary, secondary, tertiary legal materials. Conclusions from the study The terms of the new work entered beyond those promised by the West Bandung Regency Company were entered by the Employer without the knowledge of the Company the terms of the new work were directly provided to the Workers without any involvement from the workers. Breaking the provisions in force in Act No. 13 of 2003 concerning Manpower.
\end{abstract}

Keywords: Employment agreement, Employment Agreement, Employment Provisions

\begin{abstract}
Abstrak. Perjanjian kerja yang di atur dalam Pasal 1601 a KUH Perdata menyebutkan kualifikasi agar suatu prjanjian dapat disebut perjanjian kerja. Kualifikasi yang di maksud adalah adanya pekerjaan, dibawah perintah, waktu tertentu dan adanya upah, sedangkan Pasal 1 angka 14 Undang -Undang Nomor 13 Tahun 2003, Perjanjian kerja adalah suatu perjanjian antara pekerja atau buruh dengan pengusaha atau pemberi kerja yang memuat syarat-syarat kerja hak dan kewajiban kedua belah pihak. Metode penelitian ini menggunakan metode pendekatan Yuridis-Normatif, yang meneliti data sekunder dengan melakukan studi kepustakaan. Teknik pengumpulan data yang digunakan adalah data sekunder dengan menggunakan bahan hukum primer, sekunder, tersier. Simpulan dari kajian Syarat kerja baru masuk diluar yang diperjanjikan oleh Perusahaan Kabupaten Bandung Barat dimasukan oleh pihak Pengusaha tanpa sepengetahuan pihak Perusahaan syarat kerja baru itu langsung diberikan kepada para Pekerja tanpa adanya kepakatan dari pihak pekerja, tentu itu melangaggar ketentuan yang berlaku dalam Undang-Undang No.13 Tahun 2003 Tentang Ketenagakerjaan.
\end{abstract}

Kata Kunci: Perjanjian kerja, Syara Kerjat, Ketentuan Ketenagakerjaan 


\section{A. Pendahuluan}

Hukum Ketenagakerjaan merupakan bagian hukum pada umumnya. Secara umum hukum ketenagakerjaan dapat dirumuskan, bahwa hukum ketenagakerjaan adalah suatu himpunan peraturan yang mengatur hubungan hukum atara pekerja, majikan atau pengusaha, organisasi pekerja, organisasi pengusaha, dan pemerintah.

Hukum ketenagakerjaan memiliki arti yakni sebagai sekumpulan peraturan yang mengatur hubungan hukum antara pekerja dengan majikan atau pengusaha dan pemerintah, termasuk didalamnya adalah proses-proses dan keputusan-keputusan yang dikeluarkan untuk merealisasikan hubungan tersebut menjdi kenyataan.

Perlindungan terhadap pekerja dimaksudkan untuk menjamin hak-hak dasar pekerja dan menjamin kesamaan kesempatan serta perlakuan tanpa diskriminasi atas apapun untuk mewujudkan kesejatraan pekerja dan keluarganya dengan tetap memperhatikan perkembangan kemajuan dunia usaha dan kepentingan pengusaha. Peraturan perundang-undangan yang terkait dengan perlindungan bagi pekerja yakni Undang-Undang no 13 Tahun 2003 tentang ketenaga kerjaan dan peraturan pelaksana dari perundang-undangan dibidang ketenagakerjaan.

Perjanjian kerja diatur dalam Bab IX Undang-Undang Ketenagakerjan Tahun 2003. Dalam Pasal 1 Angka 14 Undang-Undang Ketenagakerjaan 2003 menyebutkan bahwa perjanjian kerja adalah perjanjian antara pekerja dengan pengusaha atau pemberi kerja yang memuat syarat-syarat kerja, hak, dan kewajiban para pihak.

Pasal 1601a KUH Perdata memberikan pengertian sebagai berikut:

"Perjanjian kerja adalah suatu perjanjian dimana pihak kesatu, yaitu: Pekerja, mengikatkan dirinya untuk menyerahkan tenaganya kepada pihak lain, yaitu majikan, dengan upah selama waktu yang tertentu".

Permasalahnya dan fakta dilapangan menunjukan bahwa, walaupun perjanjian kerja sudah diatur dalam Undang-Undang No.13 2003 tentang Ketenagakerjaan, tetapi dalam kenyataanya masih saja ada pelanggaran terhadap ketenagakerjaan yaitu perjanjian kerja, perjanjian kerja tersebut hanya menguntungkan pihak pengusaha dan merugikan pihak lain yaitu pihak pekerja. Modus pelanggaran yang dilakukan oleh pengusaha yaitu membuat dan memasukan syarat kerja baru diluar yang telah diperjanjikan oleh perusahaan.

Padahal Undang-Undang No.13 2003 tentang Ketenagakerjaan sudah mengatur sedemikian rupa mengenai pembuatan dan memasukan perjanjian kerja antara pihak perusahaan dan pihak pekerja. Oleh karena itu saya ingin mengetahui lebih lanjut mengenai peraturan ketenaga kerjaan dan pelanggaran ketenagakerjaan.

\section{B. Landasan Teori}

Hukum Ketenagakerjaan merupakan bagian hukum pada umumnya. Secara umum hukum ketenagakerjaan dapat dirumuskan, bahwa hukum ketenagakerjaan adalah suatu himpunan peraturan yang mengatur hubungan hukum atara pekerja, majikan atau pengusaha, organisasi pekerja, organisasi pengusaha, dan pemerintah. Hukum ketenagakerjaan memiliki arti yakni sebagai sekumpulan peraturan yang mengatur hubungan hukum antara pekerja dengan majikan atau pengusaha dan pemerintah, termasuk didalamnya adalah proses-proses dan keputusankeputusan yang dikeluarkan untuk merealisasikan hubungan tersebut menjdi kenyataan.

Dalam Pasal 1 ayat (2) Undang-Undang Nomor 13 Tahun 2013 menyebutkan bahwa "Tenaga kerja adalah setiap orang yang mampu melakukan pekerjaan guna menghasilkan barang dan / atau jasa baik untuk memenuhi kebutuhan sendiri maupun untuk masyarakat". Perjanjian kerja diatur dalam Bab IX Undang-Undang Ketenagakerjan Tahun 2003. Dalam Pasal 1 Angka 14 Undang-Undang Ketenagakerjaan 2003 menyebutkan bahwa perjanjian kerja adalah perjanjian antara pekerja dengan pengusaha atau pemberi kerja yang memuat syaratsyarat kerja, hak, dan kewajiban para pihak.

Pasal 1601a KUH Perdata memberikan pengertian sebagai berikut:

"Perjanjian kerja adalah suatu perjanjian dimana pihak kesatu, yaitu: Pekerja, mengikatkan dirinya untuk menyerahkan tenaganya kepada pihak lain, yaitu majikan, dengan upah selama waktu yang tertentu". 
Selain pengertian normatif seperti di atas, Imam Soepomo berpendapat bahwa perjanjian kerja adalah suatu perjanjian dimana pihak kesatu (pekerja), mengikatkan diri untuk bekerja dengan menerima upah dari pihak kedua yakni (majikan), dan majikan mengikatkan diri untuk memperkerjakan buruh dengan membayar upah.

Perlindungan hukum terhadap tenaga kerja ini terjadi karena adanya suatu hubungan kerja antara pekerja dengan pengusaha, hubungan kerja ini lahir karena adanya perjanjian kerja. Pasal 1 angka 15 Undang-undang No.13 Tahun 2003 menyatakan bahwa"hubungan kerja adalah hubungan antara pengusaha dengan pekerja/buruh berdasarkan perjanjian kerja, yang mempunyai unsur pekerjaan, upah dan perintah". Pasal 1 angka 14 Undang-undang No.13 Tahun 2003 menyatakan bahwa "perjanjian kerja adalah perjanjian antara pekerja/buruh dengan pengusaha atau pemberi kerja yang memuat syarat-syarat kerja, hak dan kewajiban para pihak".

Perlindungan terhadap tenaga kerja dimaksudkan untuk menjamin hak-hak dasar pekerja/buruh dan menjamin kesamaan kesempatan serta perlakuan tanpa diskriminasi atas dasar apapun untuk mewujudkan kesejahteraan pekerja/buruh dan keluarganya dengan tetap memperhatikan perkembangan kemajuan dunia usaha. Salah satu bentuk perwujudan dari peningkatan harkat dan martabat bagi kalangan pekerja/buruh adalah perlindungan terhadap hak-hak pekerja/buruh baik yang diperjanjikan dalam Perjanjian Kerja maupun yang dituangkan dalam Peraturan Perusahaan atau Perjanjian Kerja Bersama.

Pengertian perjanjian kerja yang di atur dalam Pasal 1601 a KUH Perdata menyebutkan kualifikasi agar suatu prjanjian dapat disebut perjanjian kerja. Kualifikasi yang di maksud adalah adanya pekerjaan, dibawah perintah, waktu tertentu dan adanya upah, sedangkan Pasal 1 angka 14 Undang-Undang No.13 Tahun 2003, memberikan pengertian tentang perjanjian kerja, yaitu:

"Perjanjian kerja adalah suatu perjanjian antara pekerja atau buruh dengan pengusaha atau pemberi kerja yang memuat syarat - syarat kerja hak dan kewajiban kedua belah pihak".

pasal 1 angka 1 Undang - Undang Ketenagakerjaan mengartikan perjanjian kerja adalah perjanjian antara pekerja dengan pengusaha atau pemberi kerja yang memuat syarat - syarat kerja, hak, dan kewajiban para pihak. Perjanjian tersebut menetapkan antara lain bahwa pekerja akan sanggup melakukan pekerjaan atau tugas yang di perintahkan padanya yang dapat menghasilkan barang atau jasa dengan satu kompensasi dari pengusaha atau pemberi kerja berupaupah yang besarnya tidakkurang dari upah minimum yang berlaku pada saat itu.

\section{Hasil Penelitian dan Pembahasan}

Mengenai masuknya perjanjian kerja baru penulis berpendapat terdapat beberapa aturan yang yang harus diperhatikan seperti yang disebutkan dalam Pasal 52 Ayat (1) Undang-Undang Nomor 13 Tahun 2003, Perjanjian kerja dibuatatas dasar yaitu Kesepakatan kedua belah pihak, Kemampuan atau kecakapan melakukan perbuatan hokum, Adanya pekerjaan yang dijanjikan. Sedangkan Menurut Pasal 1320 KUH Perdata perjanjian kerja akan menjadi sah jika memenuhi ketentuan sebagai berikut: Sepakat mereka yang mengikatkan dirinya, Kecakpan untuk membuat suatu perjanjian, Suatu hal tertentu, Sebab yang halal. Banyaknya yang melanggar peraturan tersebut demi kepentingan pihak perusahaan sehingga berdampak pada adanya pihak yang dirugikan yaitu pihak pekerja.

Dalam pembuatan perjanjian kerja Pasal 111 ayat (1) UU No.13 tahun 2003 mengatur bahwa Peraturan Perusahaan sekurang-kurangnya memuat sebagai berikut:

1. hak dan kewajiban pengusaha;

2. hak dan kewajiban pekerja/buruh;

3. syarat kerja;

4. tata tertib perusahaan; dan

5. jangka waktu berlakunya Peraturan Perusahaan.

Hal tersebut sering tidak dipatuhi oleh para pengusaha dalam pembuatan aturan perjanjian kerjanya yang tentu saja merugikan piahk pekerja.

Lalu mengenai masuknya syarat kerja baru diluar yang diperjanjikan oleh pihak pengusaha tidak semunya menyalahi ketentuan-ketentuan yang berlaku, tapi ada beberapa syarat 
kerja yang menyalahi ketentuan yang terdapat dalam undang-undang No.13 Tahun 2003. Pihak pengusaha hanya mementingkan pihak pengusaha dan tidak memikirkan pihak pekerja mengenai kerugian yang timbul dari memasukan syarat kerja yang berdampak merugikan pihak pekerja. Seperti yang dilihat pelanggaran-pelanggaran tersebut dibuat oleh pengusaha dan tidak adanya sangktpaut perusahaan karna tidak adanya kordinasi terhadap pihak pengusaha terhadap perusahaan.

\section{Kesimpulan}

Berdasarkan pembahasan dalam penelitian ini, peneliti menyimpulkan beberapa hasil penelitian, yaitu :

Dalam membuat perjanjian kerja sudah memenuhi ketentuan yang ada dalam UndangUndang No.13 Tahun 2003 Tentang Ketenagakerjaan terhadap para pekerjanya, namun pihak pengusaha melakukan pelanggaran terhadap ketententuan yang ada dalam ketentuan membuat syarat kerja dan memasukan syarat kerja pada intinya pihak peperusahaan sendiri sudah memenuhi ketentuan yang ada dalam Undang-Undang No.13 Tahun 2003 Tentang Ketenagakerjaan.

Masuknya syarat kerja yang di lakukan oleh pengusaha telah melanggar UndangUndang No.13 Tahun 2003 Tentang Ketenagakerjaan mengenai hak para pekerjanya dan tidak ada tindak lanjut dari perusahaan terhadap pengusahanya. Tidak semua syarat kerja yang dibuat oleh pihak pengusaha itu melanggar ketentuan yang ada hanya saja ada beberapa syarat kerja yang merugikan pihak pekerja.

\section{Daftar Pustaka}

Buku

[1] Imam Soepomo, Pengantar Hukum Perburuhan, Djambatan, Jakarta, 1983.

[2] Lalu Husni, Pengantar Hukum Ketenagakerjaan Indonesia, Raja Grafindo, Jakarta, 2000.

[3] R. Joni Bambang, Hukum Ketenagakerjaan, Pustaka Setia, Bandung, 2013

[4] Abdul Khakim., Dasar-Dasar Hukum Ketenagakerjaan Indonesia, PT.CITRA ADITYA BAKTI, Bandung, 2014.

Undang-undang

[5] Undang-Undang Nomo 13 Tahun 2003 tentang Ketenagakerjaan.

[6] Undang-Undang Hukum Perdata 